DOI: $10.4274 /$ tjh.2016.0199

Turk J Hematol 2017;34:352-353

\title{
Giant Intracranial Solitary Plasmacytoma
}

\author{
Intrakraniyal Dev Plazmositom
}

\author{
Osman Kara ${ }^{1}$, Tayfur Toptaş ${ }^{1}$, Işık Atagündüz ${ }^{1}$, Süheyla Bozkurt² ${ }^{2}$ Önder Şirikçi ${ }^{3}$, Tülin Fıratlı Tuğlular ${ }^{1}$ \\ ${ }^{1}$ Marmara University Faculty of Medicine, Department of Hematology, Istanbul, Turkey \\ ${ }^{3}$ Marmara University Hospital Faculty of Medicine, Department of Pathology, Istanbul, Turkey \\ ${ }^{3}$ Marmara University Hospital Faculty of Medicine, Department of Biochemistry, Istanbul, Turkey
}

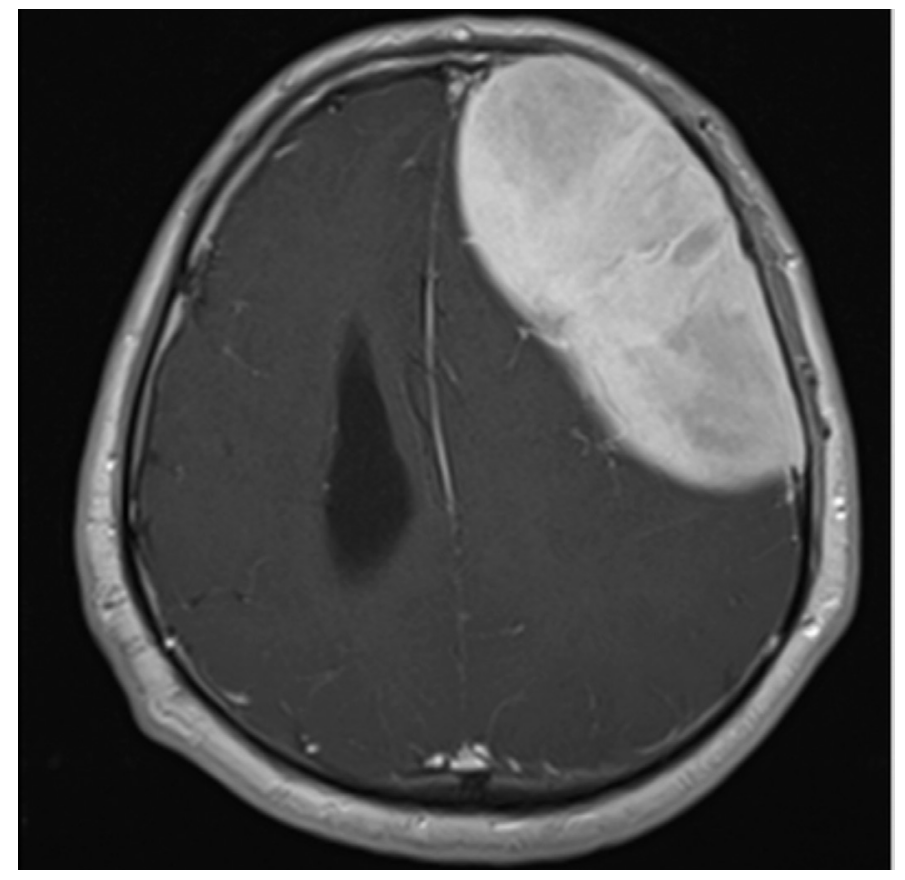

Figure 1. The mass occupied the left frontoparietal region, displacing the left lateral ventricle and causing a shift of the midverge of the brain.

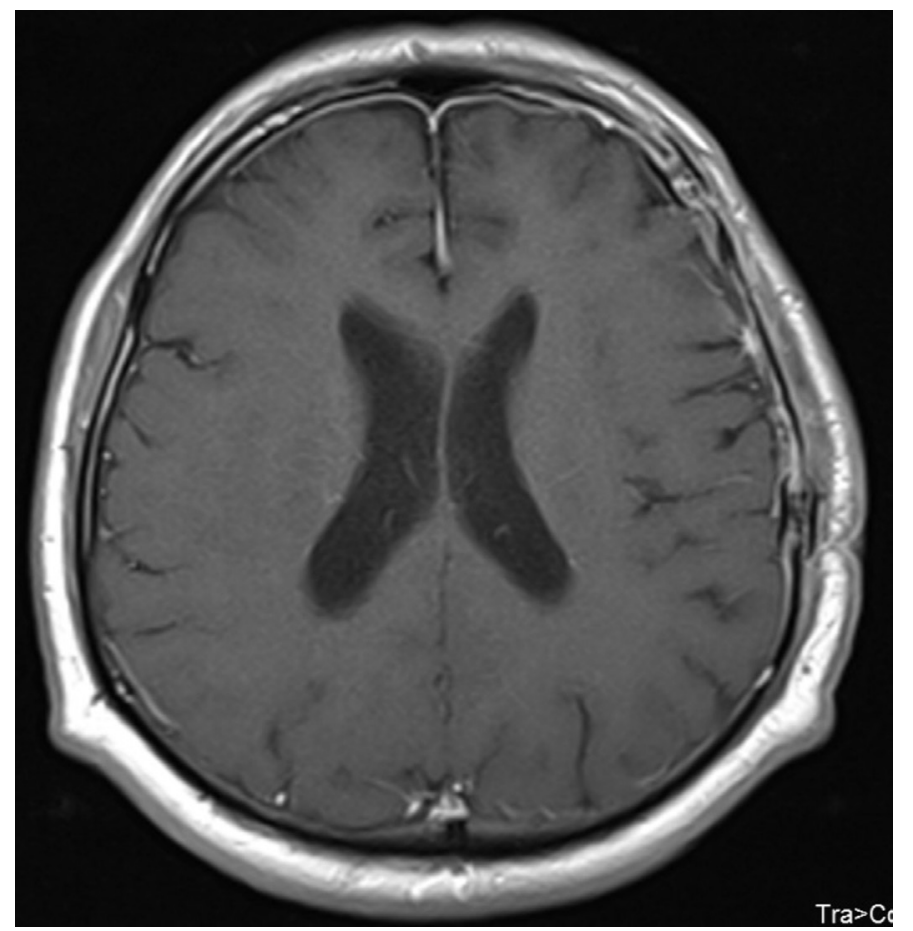

Figure 2. Postoperative cranial magnetic resonance imaging.
A 41-year-old man presented with complaints of severe headache and vomiting during the last 5 days. Neurological and systemic examination revealed no abnormality. A mass of $112 \times 49 \mathrm{~mm}$, which occupied the left frontoparietal parenchymal region, was evident on the $T_{1}$ sequence of magnetic resonance imaging (Figure 1). This homogeneous contrasted mass displaced the left lateral ventricle and caused a shift of the mid-verge of the brain. The mass was totally removed (Figure 2). Pathological examination revealed a plasma cell dyscrasia with lambda monoclonality.
Bone marrow biopsy was consistent with a clonal plasma cell accumulation of 5\%. Two tiny M-protein peaks were detected on serum protein electrophoresis, which was compatible with immunoglobulin (Ig) G-and IgA-lambda monoclonal bands on serum immunofixation electrophoresis (Figure 3). There were no other plasmacytomas or lytic lesions detected with positron emission tomography-computed tomography imaging. The patient was diagnosed with a solitary plasmacytoma and treated with radiotherapy only. He had no complaints at the sixth month after diagnosis.

๑Copyright 2017 by Turkish Society of Hematology

Turkish Journal of Hematology, Published by Galenos Publishing House

口. Address for Correspondence/Yazışma Adresi: Osman KARA, M.D.,

Marmara University Faculty of Medicine, Department of Hematology, İstanbul, Turkey 

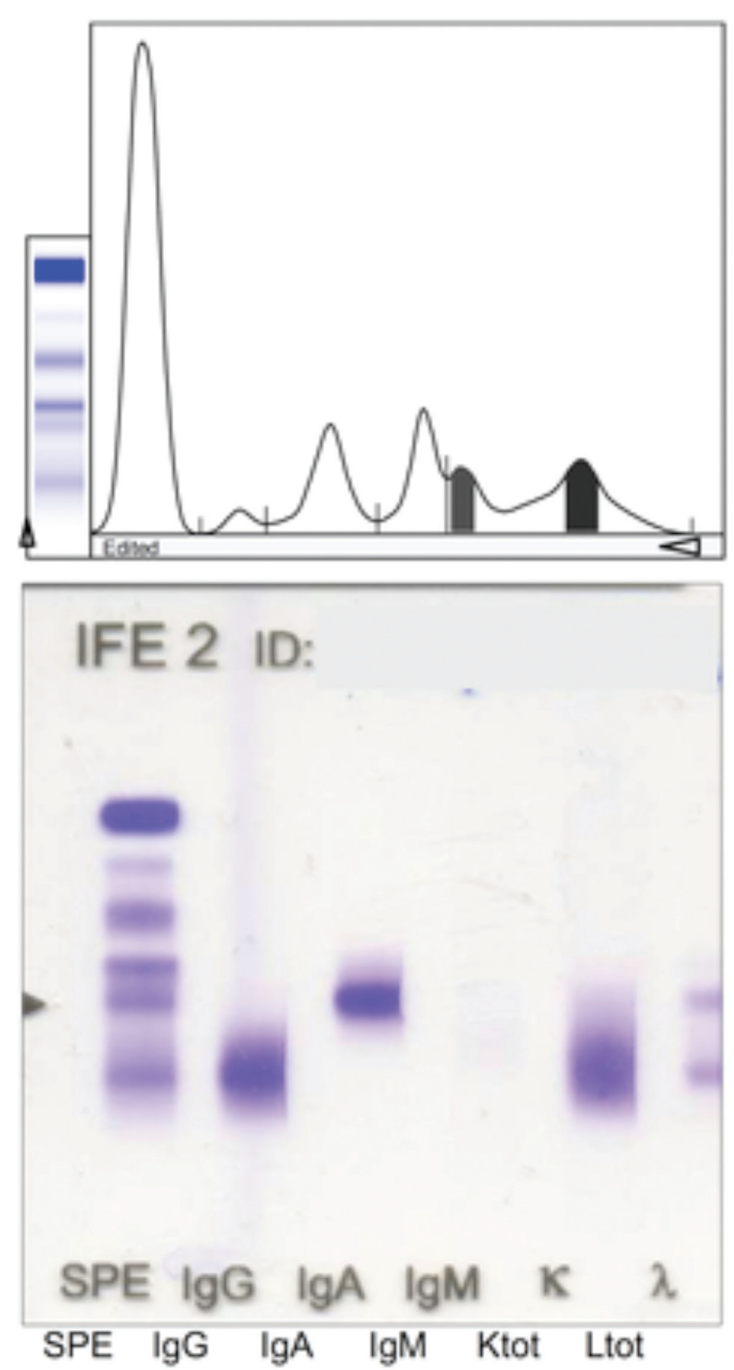

Figure 3. M-protein peaks on serum protein electrophoresis and monoclonal bands on immunofixation electrophoresis are depicted.

Ig: Immunoglobulin.
Keywords: Plasmacytoma, Myeloma, Intracranial

Anahtar Sözcükler: Plazmasitom, Miyelom, Intrakraniyal

Informed Consent: Was obtained from the patient.

Conflict of Interest: The authors of this paper have no conflicts of interest, including specific financial interests, relationships, and/or affiliations relevant to the subject matter or materials included. 